\title{
Estimating Conveyance Efficiency and Maize Productivity of Traditional Irrigation Systems in Usa River Catchment, Tanzania
}

\author{
Humuri K. Haymale $\mathbb{D}^{1,2}$ Karoli N. Njau, ${ }^{1}$ and Frederick C. Kahimba ${ }^{3}$ \\ ${ }^{1}$ Department of Water Environmental Sciences and Engineering (WESE), \\ The School of Materials Energy Water and Environmental Sciences (MEWES), \\ The Nelson Mandela African Institution of Science and Technology (NM-AIST), P.O. Box 447, Arusha, Tanzania \\ ${ }^{2}$ Arusha Technical College, Department of Civil Engineering, P.O. Box 296, Arusha, Tanzania \\ ${ }^{3}$ Tanzania Engineering and Manufacturing Design Organisation (TEMDO), Plot No. 268 Block B Njiro Hills, P.O. Box 6111, \\ Arusha, Tanzania
}

Correspondence should be addressed to Humuri K. Haymale; haymalehk@gmail.com

Received 8 February 2020; Revised 2 June 2020; Accepted 23 June 2020; Published 30 July 2020

Academic Editor: Mathias N. Andersen

Copyright (C) 2020 Humuri K. Haymale et al. This is an open access article distributed under the Creative Commons Attribution License, which permits unrestricted use, distribution, and reproduction in any medium, provided the original work is properly cited.

\begin{abstract}
Estimating the conveyance efficiency of traditional irrigation schemes systems is very important. It is because of understanding the volume of water lost along with the transportation facility, enhancing water usage and productivity, hence making better decisions about the utilization of water resources. The objective of the study was to determine water abstraction permit compliances and estimate conveyance efficiency and crop and water productivity of traditional irrigation systems in northern Tanzania. The task involved measurement of irrigation water flows to determine the amount of water abstraction, inflow (head) and outflow (tail) between the canals to determine the conveyance efficiency of the main, secondary, and tertiary canals of the traditional irrigation systems. Moreover, water and yield obtained at the farm level were determined. Results indicate that approximately $72 \%$ of water transported reaches the destined farm which produced maize (Zea mays L) yields of $1054.5 \mathrm{~kg} / \mathrm{ha}, 892.4 \mathrm{~kg} / \mathrm{ha}$, and $875.156 \mathrm{~kg} / \mathrm{ha}$ at downstream, midstream, and upstream which equals $0.41 \mathrm{~kg} / \mathrm{m}^{3}, 0.15 \mathrm{~kg} / \mathrm{m}^{3}$, and $0.09 \mathrm{~kg} / \mathrm{m}^{3}$, respectively, while about $28 \%$ of water is lost along the canals through evaporation, seepage, and deep percolation and overtopping. Consequently, water measured at furrow intakes in total was $3,500 \mathrm{~L} / \mathrm{s}$, equal to $23 \%$ more than the permitted amount of $2856.14 \mathrm{~L} / \mathrm{s}$ at Usa River Catchment. Interventions to minimize water losses starting at the furrow's intakes are urgently required in the current trend of the increasing demand for water resources for food production and schemes performance. Subsequently, more effective conveyance technologies and water management strategies other than canal lining are required.
\end{abstract}

\section{Introduction}

Globally rain-fed agriculture's contribution to food production is about $60 \%$; the other $40 \%$ is supplemented by irrigated agriculture [1]. However, irrigation consumes about $70 \%$ of the available water [2]. Globally, approximately 277 million hectares of agricultural land is under irrigation (about $20 \%$ of cultivated land), contributing $40 \%$ of the food supplies with 2.3 higher yields compared to rain-fed agriculture as described by Adejumobi et al. [3]. Irrigation efficiency in Sub-Saharan Africa (SSA) was 33\% in the year 1998 and is expected to improve by $37 \%$ by the year 2030 [1].
The SSA irrigated agriculture is said to use less than $2 \%$ of the total renewable water resources to irrigate a land of six million hectares, which is equal to $6 \%$ of the total irrigable land. Conversely, Asia region uses $37 \%$ and Latin America uses $17 \%$ of its total renewable water resources, which seem to be higher than SSA [1]. Utilization of water for irrigation needs a lot of attention in the catchment with scarce water resource. The performance indication of the irrigation schemes is revealed from the irrigation efficiency.

Generally, water from the source is being conveyed through different methods depending on the establishment of the scheme in terms of conveyance distribution and 
application system. Currently, the conveyance efficiencies for the traditional irrigation schemes in Tanzania range within $70 \%-80 \%$ for the main canal, $50 \%-80 \%$ for the secondary canal, and $23 \%-63 \%$ for a tertiary canal [4]. The different conveyance distribution facilities used include open lined canals, pipes, and earthen canals, which ensure water travel from the source to the farm field. It is believed that most water is being lost during distribution and application in the farm fields. However, conveyance efficiencies mainly relate to the engineering of the infrastructure, while the application efficiencies relate to farmer/agronomic practices [5]. Traditional irrigation schemes in the country rely on the runoff of the river abstraction and gravity flows with the irrigation infrastructures in the state of being temporal and poorly constructed and thus pose difficulty to water abstraction and overall water management, with low irrigation efficiencies. The conveyance efficiency of the irrigation schemes provides insight into the performance of the infrastructure and enhances water resource utilization. In the Usa River Catchment, the irrigation infrastructure is earthen traditional canals and does not have the capacity of holding and maintaining the intended quantity of water directed to the fields. Irrigation canal performance is part of the overall enactment of an irrigation area [6].

Tanzania has a total of 1,428 irrigation schemes where 1,328 are smallholders, 85 are private sectors, and 15 are government-owned [7]. The largest irrigation schemes are found in Kilimanjaro, Arusha, Morogoro, Iringa, and Mbeya [7]. Irrigated agriculture in Tanzania reportedly consumes approximately $89 \%$ of the total water diverted, compared to $9 \%$ domestic use and $2 \%$ industrial water use [8]. Simultaneously, on-farm water use efficiency is typically very low, within $10 \%-20 \%$, contributing to the heavy use of water for irrigation [8].

The conveyance efficiency normally dictates the amount of water to be delivered to the field, which depends on the characteristics of the channel. In the process of transporting water from the source to the farm/land, there is water loss through evaporation, transpiration, percolation, and spills. Consequently, the distance from the water source to the farmland, soil type, channel type and the slope of the channel are the other main causes of water losses.

A similar situation can also be found in the Usa River Catchment which is located in the Arusha region, near Arusha town. The catchment has about twenty (20) identified irrigation schemes that extract water from the rivers in the catchment (Figure 1). The catchment is water-stressed due to excessive withdrawal from surface and groundwater for irrigated farming of diverse crops.

However, no research has been conducted to understand the irrigation conveyance efficiencies and crop and water productivity in the Usa River Catchment. The efficiencies and productivity of the irrigation schemes remain a policy question for the basin water managers and decision-makers. There is a general assumption that some water can be released from the Usa Rivers to irrigation schemes. Similarly, it is not clear where to target such water-saving interventions.

Therefore, this study intended to estimate the conveyance efficiency and crop and water productivity in traditional

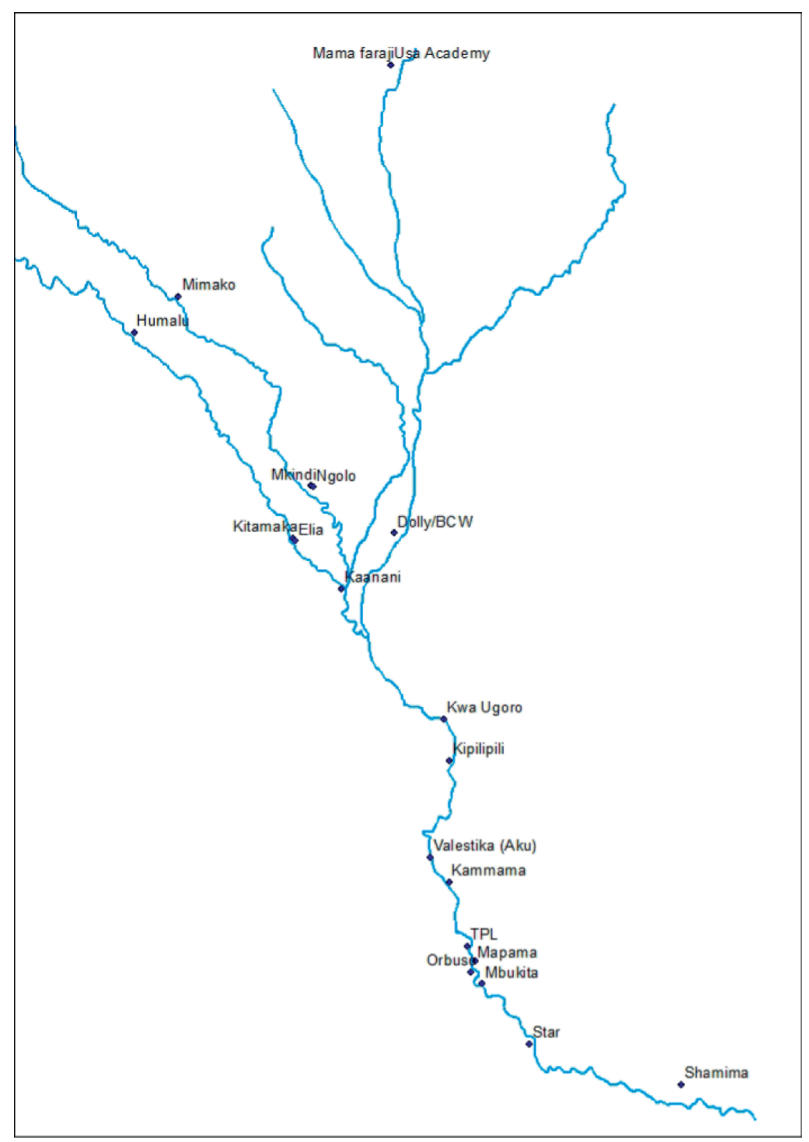

FIGURE 1: Irrigation water intakes and location.

irrigation schemes and irrigation practices in the Usa River Catchment where there are many farmers-managed irrigation schemes that the basin authority considers to have poor infrastructure, poor water management, and low yields.

\section{Materials and Methods}

2.1. Study Area Description. This study was carried out at the Usa River Catchment, within the Upper Pangani River Basin, North of Tanzania. The catchment is located within the northern region of Tanzania at $3^{0} 15^{\prime} 00^{\prime \prime}$ to $3^{0} 33^{\prime} 00^{\prime \prime} \mathrm{S}$ and longitude $36^{\circ} 45^{\prime} 00^{\prime \prime}$ to $36^{\circ} 58^{\prime} 00^{\prime \prime} \mathrm{E}$ (Figure 2). The catchment has an area of $320 \mathrm{~km}^{2}$ and forms part of the larger Kikuletwa Catchment. The catchment is located at the foot of Meru Mountain lying between Kikavu River Catchment running from Kilimanjaro Mountain and Nduruma River Catchment running from Meru Mountain. The rivers found within the catchment running from Meru Mountains include Malala, Tengeru, Usa River, Maji ya Chai, Mogadirisho, and Ngaresero, which discharge water in Kikuletwa River (Figure 2). The Usa River Catchment consists of administrative wards of Songoro, Nkoaranga, Maji ya Chai, Usa River, Kikwe, Seela, Singisi, and Poli. The largest plain area is found downstream of the catchment where the largest farms are located. The downstream of the catchment is at $914 \mathrm{~m}-1194 \mathrm{~m}$, above-average mean sea level. 


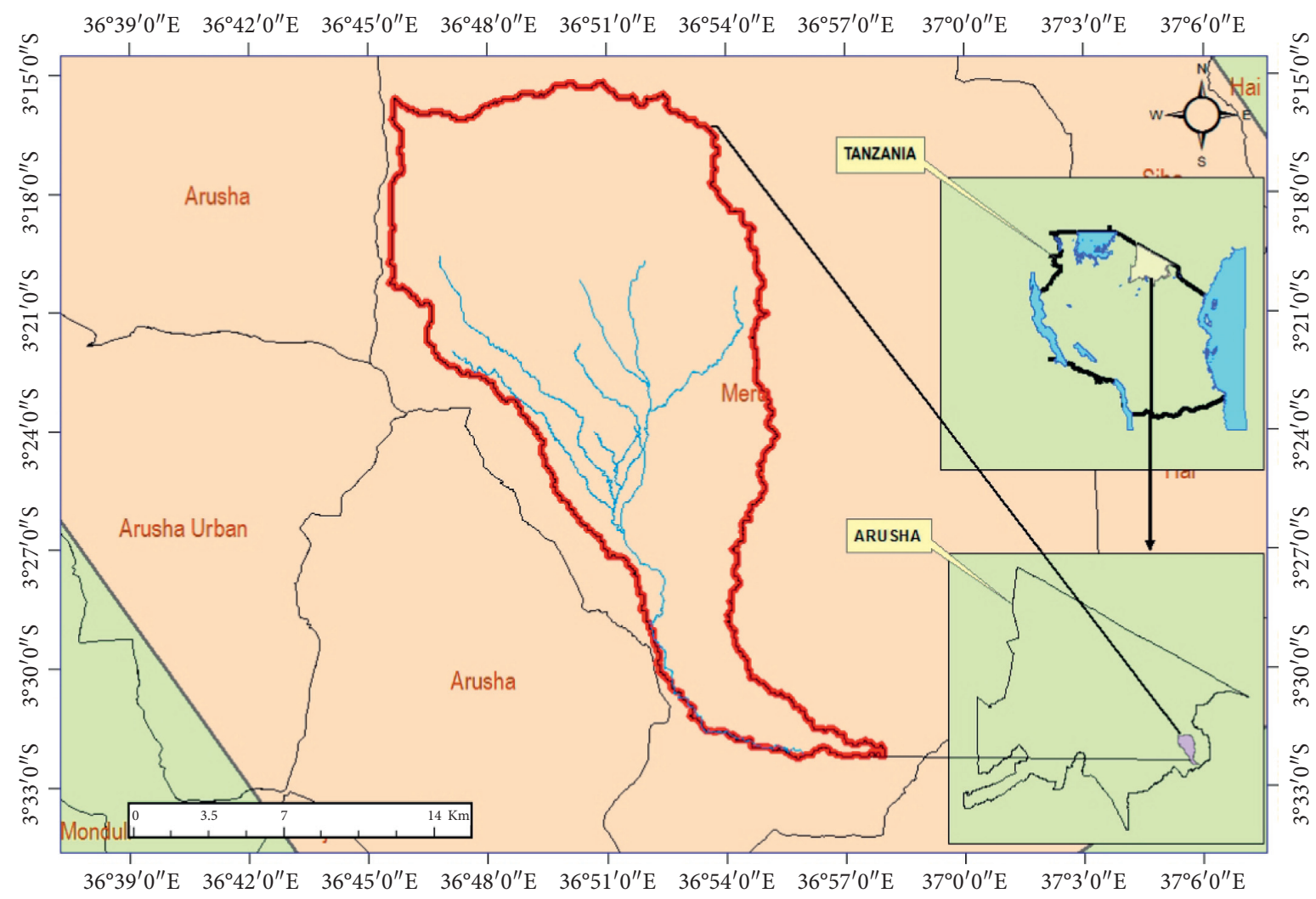

Figure 2: Usa river catchment location.

2.1.1. Topography of the Catchment. The topography of the Usa River Catchment is generally characterized by a slightly rolling plain from Mbuguni ward which steepens towards the foot of Meru Mountain where the rivers start. The average elevation is $1100 \mathrm{~m}$ above the mean sea level and the slope is dissected by the permanent, perennial, and seasonal rivers. Small springs are found in the middle part of the catchment which also recharges the rivers. The large area of the catchment is exhausted by anthropogenic activities like agriculture, pastoralists, and habitation. The land formation of the catchment is partly rocky, which is covered by the small layer of soil that supports the life of the living things and agricultural activities and partly is fertile soil. Moreover, the northern part of the catchment is where the Arusha National Park is located, which helps to recharge rivers due to the presence of forests. The hydrogeology of the catchment allows underground water movement as a result of recharging the available water resource and the soil reserving moisture for irrigation agriculture. Therefore, the area has great potential for irrigated agriculture due to the market demand for agricultural products to be supplied to the nearby populated City of Arusha.

\subsection{Catchment Delineation and Intake Furrow Measurement.} The catchment was delineated using ArcSwat Software from the Digital Elevation Model DEM of the area with a resolution of $30 \mathrm{~m} \times 30 \mathrm{~m}$. The Digital Elevation Model was derived from the United States Geological Survey USGS data from 1995 to 2015 (Figure 2). Subsequently, irrigation water intakes (furrows) were located using coordinates taken by Garmin 60s GPS device (Figure 1) from upstream to the downstream followed by water intakes measurement using a current flow meter (SEBA Universal Meter F1 device with propeller $125 \mathrm{~mm}$ and pitch $300 \mathrm{~mm}$ ). Additional data on the amount of water permitted per irrigation scheme was collected from the Pangani Basin Water Board Office (Table 1).

2.3. Conveyance Efficiency Determination. The flow measurement using current meter (SEBA Universal Meter F1 with propeller $125 \mathrm{~mm}$ and pitch $300 \mathrm{~mm}$ ) device as shown in Figure 3 was carried out at every division point of the channel from the intake of the irrigation canal to the fields (Figure 4). The raw data were converted to flow rate (volume) using calibration formulae of the respective current meter impeller used. The difference between the inflow (head) and the outflow (end) of every segment was computed to determine the quantity of water lost in each of the segments as conveyance efficiency (Table 2). Furthermore, distances of one section of the channel were estimated using the GPS set to the distance calculation mode and walk along or near the section. The locations where the water flow measurements were taken at the intake (head), channel junctions (end/head), and the other point along the channel (end) are shown in Figure 4:

$$
Q_{\text {Dischargeloss }}=Q_{\text {head }}-Q_{\text {tail }} \text {, }
$$


TABLE 1: List of irrigation furrows with measured water abstraction at the intakes and water permits in Sept 2017.

\begin{tabular}{|c|c|c|c|c|c|c|c|}
\hline $\mathrm{S} / \mathrm{N}$ & Furrow name & Permit no. & Quantity permitted (L/s) & Quantity measured (L/s) & $\%$ of abstraction & River source & Status intake \\
\hline 1 & Shamima & 140236 & 200 & 189 & 95 & Kikuletwa & With gate \\
\hline 2 & Star & 140616 & 68 & 70 & 103 & Kikuletwa & Without gate \\
\hline 3 & Mbukita & 140237 & 200 & 151 & 76 & Kikuletwa & Without gate \\
\hline 4 & Orbuso & 2285 & 200 & 215 & 108 & Kikuletwa & With gate \\
\hline 5 & TPL & 3156 & 280.3 & 130 & 46 & Kikuletwa & With gate \\
\hline 6 & Mapama & 140550 & 300 & 242 & 81 & Kikuletwa & With gate \\
\hline 7 & Kammama & 140040 & 200 & 204 & 102 & Kikuletwa & With gate \\
\hline 8 & Valestika & 3727 & 142.2 & 130 & 91 & Kikuletwa & Without gate \\
\hline 9 & Kipilipili & 3151 & 14.16 & 147 & 1038 & Kikuletwa & O/gate/repair \\
\hline 10 & Kwa Ugoro & 4761 & 113.28 & 150 & 132 & Kikuletwa & Without gate \\
\hline 11 & Dolly/BCW & 1765 & 84.96 & 224 & 264 & USA & With gate \\
\hline 12 & Kaanani & 1110055 & 200 & 135 & 68 & Malala & Without gate \\
\hline 13 & Kitamaka & 140014 & 200 & 138 & 69 & Malala & With gate \\
\hline 14 & Elia & 140046 & 20 & 69 & 345 & Malala & Without gate \\
\hline 15 & Mkindi & 140047 & 100 & 83 & 83 & Tengeru & with gate \\
\hline 16 & Ngolo & 14007 & 100 & 115 & 115 & Tengeru & Without gate \\
\hline 17 & Humalu & 11101807 & 50 & 55 & 110 & Malala & Without gate \\
\hline 18 & Mimako & 140191 & 85 & 227 & 267 & Tengeru & With gate \\
\hline 19 & Furrow No.1 & 11101545 & 100 & 453 & 453 & USA & Without gate \\
\hline \multirow[t]{2}{*}{20} & Makiba & 3143 & 198.24 & 373 & 188 & Kikuletwa & Without gate \\
\hline & & & 2856.14 & 3500 & & & \\
\hline
\end{tabular}

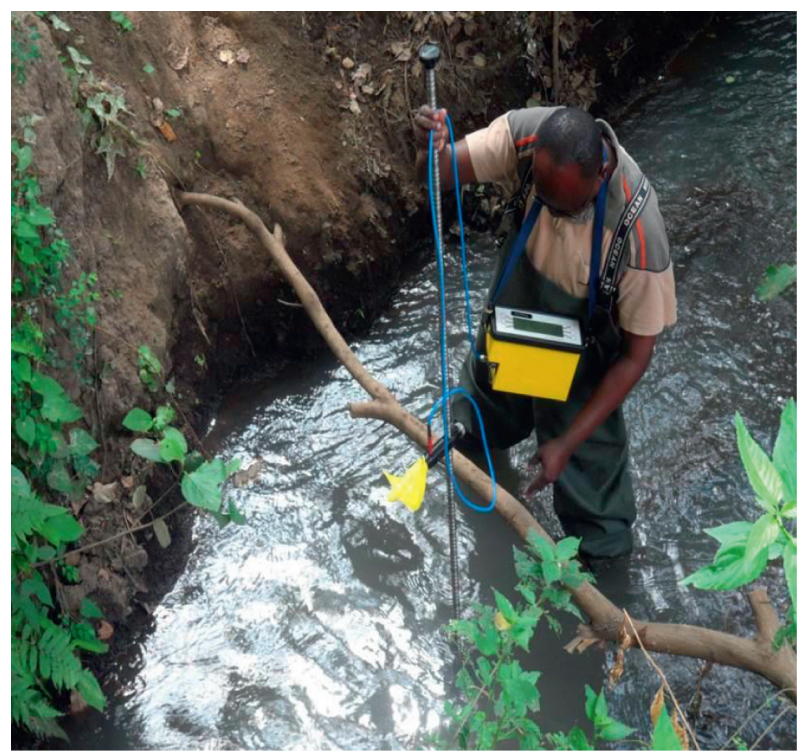

Figure 3: Water flow measurement at traditional canal using current meter.

where $Q_{\text {Dischargeloss }}$ means quantity of water lost in a channel in $L / s, Q_{\text {head }}$ means quantity of water at the head (inflow) in $\mathrm{L} / \mathrm{s}$, and $\mathrm{Q}_{\text {tail }}$ means quantity of water at the end of channel (outflow) $\mathrm{L} / \mathrm{s}$.

Discharge loss in percentage $(Q \%)$ is as follows:

$$
Q_{\text {Loss } \%}=\frac{Q_{\text {inflow }}-Q_{\text {outflow }}}{Q_{\text {inlow }}},
$$

where $Q_{\text {inflow }}$ is water quantity at the channel head $(\mathrm{L} / \mathrm{s})$ and $Q_{\text {outflow }}$ is water quantity at the channel tail $(\mathrm{L} / \mathrm{s})$.

Conveyance efficiency $\left(E_{c}\right)$ is as follows:

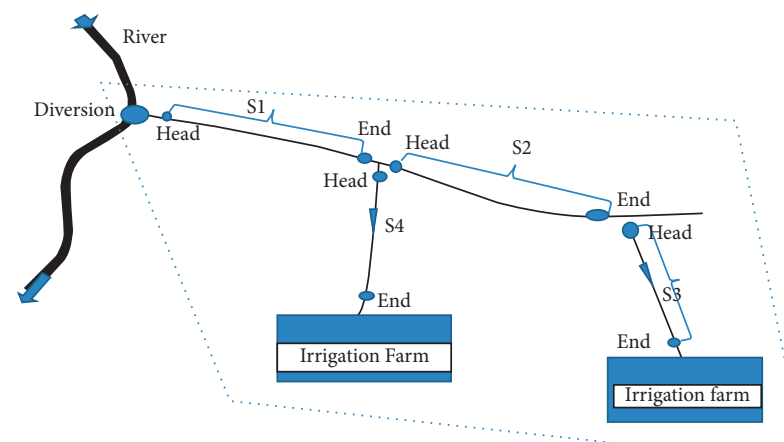

FIgURE 4: Typical layout of traditional irrigation scheme infrastructure $(\mathrm{s}=$ section$)$.

$$
E_{c}=\frac{Q_{\text {outflow }}}{Q_{\text {inlow }}} \times 100 \% .
$$

2.4. Crop Water Productivity Determination. In order for the crop plant to grow, water, soil, nutrient, and sunlight in terms of energy are needed. During their growth, plants tend to develop organic matter where in turn dry matter is obtained. During the data collection for crop water productivity, the pieces of lands of $110 \mathrm{~m} \times 95 \mathrm{~m}, 98 \mathrm{~m} \times 102 \mathrm{~m}$, and $89 \mathrm{~m} \times 90 \mathrm{~m}$ size for downstream, midstream, and upstream, respectively, were identified. In our study, maize (Zea mays L) crop was selected because it is the staple food. Similarly, the irrigation schedule at every plot was monitored while the amount of water irrigated was measured using current meter and calculated. Subsequently, the produce from each plot was harvested, dried, and then weighed. 
Table 2: Conveyances efficiencies.

\begin{tabular}{|c|c|c|c|c|c|c|c|c|}
\hline \multirow[t]{2}{*}{ Furrow name } & \multirow[t]{2}{*}{ Canal section } & \multicolumn{2}{|c|}{$\begin{array}{c}\text { Discharge extracted } \\
(\mathrm{L} / \mathrm{s})\end{array}$} & \multirow{2}{*}{ Distance (m) } & \multirow[t]{2}{*}{ Discharge loss (L/s) } & \multirow[t]{2}{*}{ Discharge loss L/s/m } & \multirow[t]{2}{*}{ Loss $\%$} & \multirow[t]{2}{*}{ Efficiency \% $\left(E_{c}\right)$} \\
\hline & & $\mathrm{H} /$ section & E/section & & & & & \\
\hline \multirow{2}{*}{ Shamima } & Section 1 & 189 & 105 & 1902 & 84 & 0.044 & 44.4 & 55.6 \\
\hline & Section 2 & 83 & 53 & 891 & 29 & 0.033 & 35.5 & 64.5 \\
\hline Star & Section 1 & 70 & 41 & 1183 & 29 & 0.025 & 41.4 & 58.6 \\
\hline Mbukita & Section 1 & 72 & 53 & 716 & 19 & 0.027 & 26.4 & 73.6 \\
\hline \multirow{2}{*}{ Orbuso } & Section 1 & 209 & 152 & 3648 & 57 & 0.016 & 27.3 & 72.7 \\
\hline & Section 2 & 100.5 & 98 & 273 & 3 & 0.011 & 2.5 & 97.5 \\
\hline $\mathrm{TPL}$ & Section 1 & 153.3 & 136.1 & 2251 & 17 & 0.008 & 11.2 & 88.8 \\
\hline \multirow[t]{2}{*}{ Mapama } & Section 1 & 429 & 162 & 3924 & 267 & 0.068 & 62.3 & 37.7 \\
\hline & Section 1 & 223 & 209 & 864 & 13 & 0.015 & 6 & 94 \\
\hline \multirow{3}{*}{ Kammama } & Section 2 & 196 & 161 & 202 & 34 & 0.168 & 17.5 & 82.5 \\
\hline & Section 3 & 81 & 74 & 454 & 7 & 0.015 & 8.5 & 91.5 \\
\hline & Section 4 & 71 & 58 & 1148 & 13 & 0.011 & 18.8 & 81.2 \\
\hline \multirow{3}{*}{ Valestika } & Section 1 & 152 & 87 & 2270 & 65 & 0.029 & 42.8 & 57.2 \\
\hline & Section 2 & 48 & 30 & 873 & 18 & 0.021 & 37.5 & 62.5 \\
\hline & Section 1 & 447 & 297 & 2228 & 150 & 0.067 & 33.5 & 66.5 \\
\hline \multirow[t]{2}{*}{ Kipilipili } & Section 2 & 132 & 125 & 262 & 7 & 0.027 & 5 & 95 \\
\hline & Section 3 & 54 & 43.3 & 1109 & 11 & 0.010 & 20.4 & 79.6 \\
\hline \multirow{3}{*}{ Kwa Ugoro } & Section 1 & 448 & 82.5 & 3128 & 365 & 0.117 & 81.6 & 18.4 \\
\hline & Section 2 & 46 & 26 & 1781 & 20 & 0.011 & 43.1 & 56.9 \\
\hline & Section 1 & 257 & 221.7 & 1357 & 35 & 0.026 & 13.6 & 86.4 \\
\hline \multirow[t]{2}{*}{ Dolly/BCW } & Section 2 & 132 & 123 & 898 & 9 & 0.010 & 7.1 & 92.9 \\
\hline & Section 3 & 81 & 27 & 2546 & 54 & 0.021 & 66.8 & 33.2 \\
\hline \multirow{2}{*}{ Kaanani } & Section 1 & 198 & 120.9 & 1457 & 77 & 0.053 & 38.8 & 61.2 \\
\hline & Section 2 & 99 & 19.7 & 830 & 79 & 0.095 & 80.1 & 19.9 \\
\hline Kitamaka & Section 1 & 41 & 39 & 20 & 2 & 0.100 & 4.9 & 95.1 \\
\hline Elia & Section 1 & 22 & 8 & 672 & 15 & 0.022 & 65.4 & 34.6 \\
\hline Mkindi & Section 1 & 37 & 33.9 & 345 & 3 & 0.009 & 9.1 & 90.9 \\
\hline Ngolo & Section 1 & 143 & 100 & 1215 & 43 & 0.035 & 30.1 & 69.9 \\
\hline \multirow{3}{*}{ Humalu } & Section 1 & 48 & 40 & 504.5 & 8 & 0.016 & 16.7 & 83.3 \\
\hline & Section 2 & 32 & 24 & 69 & 8 & 0.116 & 25 & 75 \\
\hline & Section 1 & 94 & 90 & 634 & 4 & 0.006 & 4.4 & 95.6 \\
\hline \multirow[t]{3}{*}{ Mimako } & Section 2 & 58 & 48 & 931 & 10 & 0.011 & 17.5 & 82.5 \\
\hline & Section 3 & 42 & 35 & 463 & 7 & 0.015 & 16.7 & 83.3 \\
\hline & Section 1 & 440 & 415 & 1452 & 25 & 0.017 & 5.7 & 94.3 \\
\hline \multirow{3}{*}{ Furrow no. 1} & Section 2 & 335 & 330 & 975 & 5 & 0.005 & 1.4 & 98.6 \\
\hline & Section 3 & 310 & 271 & 1321 & 39 & 0.030 & 12.5 & 87.5 \\
\hline & Section 4 & 82 & 45 & 531 & 37 & 0.070 & 45.1 & 54.9 \\
\hline Makiba & Section 1 & 373 & 221 & 846 & 152 & 0.180 & 40.8 & 59.2 \\
\hline Total & & & & & Averages & 0.041 & 28.1 & 71.9 \\
\hline
\end{tabular}

\section{Results}

3.1. Field Survey Result. During the field visit observation, twenty (20) furrow intakes were identified in the catchment (Figure 1). A number of furrow intakes were located at midstream and downstream of the catchment. Upstream of the catchment is steep and has small streams that accommodate the irrigation during the dry season.

\subsection{Water Flow Measurements}

3.2.1. Intakes. Many of the furrow intakes weirs were constructed using stones, sandbags, and tree logs (Figure 5), which do not catch water intended for irrigation and frequent maintenance. However, the weirs are provided for the purpose of directing water to the irrigation scheme and

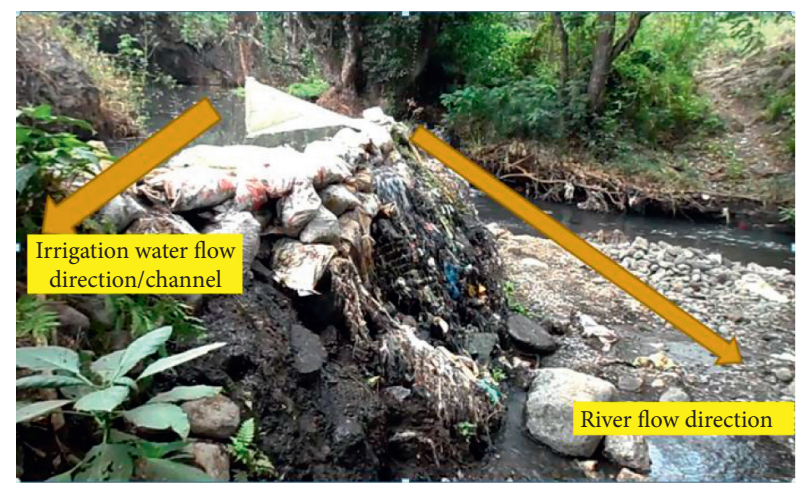

FIGURE 5: Furrow intake constructed with sand bag/stone/trees logs. 
allowing fixing water gates for regulating irrigation water flow to meet the demand of a particular farm or scheme (Figure 6). Moreover, some of the furrow intakes were constructed using reinforced concrete but still do not work to the required form (Figure 6) while others were constructed locally using stones, tree logs, and sand buckets (Figure 5).

Furthermore, water diverted at the intakes was measured to see how much is withdrawn and how much is permitted to abstract (Table 1). Information on water use permit provided and amount of water permitted to abstract was collected from the Pangani Water Office. During the measurement of water flows at the intakes, it was discovered that some of the furrow intakes abstract more water relative to the allocated amount (Table 1).In that fact, water flows at the intakes exceeded the permitted amount because the irrigation water demand of respective scheme is high or because of the issue of regulating structure that controls the amount of water to flow. The issue of monitoring the diverted water to ensure that it complies with water use permit granted to the Water User Association (WUA) is a problem within the catchment. The water irrigation furrow intakes were scattered from upstream to the downstream; however, after the river confluence going downwards there are many accumulated furrow intakes due to favoring landforms and availability of land for farming (Figure 1).

3.2.2. Irrigation Conveyance Infrastructure. The Usa River Catchment irrigation scheme's main canals, secondary, and tertiary were earthen which transport water from the intake to the scheme. The irrigation infrastructure system found in the catchment can be represented in a tree form. The main stem taps water from the soil and transports it to the branches. The branches supply the twigs with water and finally it enters into the leaves, where it will either be used by the plants for growth or be lost into the air through evaporation.

The same can be seen in Usa River Catchment traditional irrigation schemes infrastructure where main/primary canal (stem) taps water from the river and then it is distributed by the smaller secondary canal (branches) to the tertiary canal (twigs), which are smaller, and enters into the fields (Figure 4). According to the study conducted in the catchment, water losses at the canals were on average $0.041 \mathrm{Ls}^{-1} \mathrm{~m}^{-1}$ (Table 2). Further, traditional irrigation does abstract water from the source after being given water permit and conveys the same using earth canal to the farm. Moreover, the distributing structure like junction, turnout boxes, and the gate valve farmer uses traditional materials like stone, soils/ earth, and tree logs.

The same can be seen in Usa River Catchment traditional irrigation schemes infrastructure where main/primary canal (stem) taps water from the river and then it is distributed by the smaller secondary canal (branches) to the tertiary canal (twigs), which are smaller, and enters into the farm (Figure 4). According to the study conducted in the catchment, it is shown that water losses at the canals were on average of $0.041 \mathrm{Ls}^{-1} \mathrm{~m}^{-1}$ (Table 2). Further, traditional irrigation does

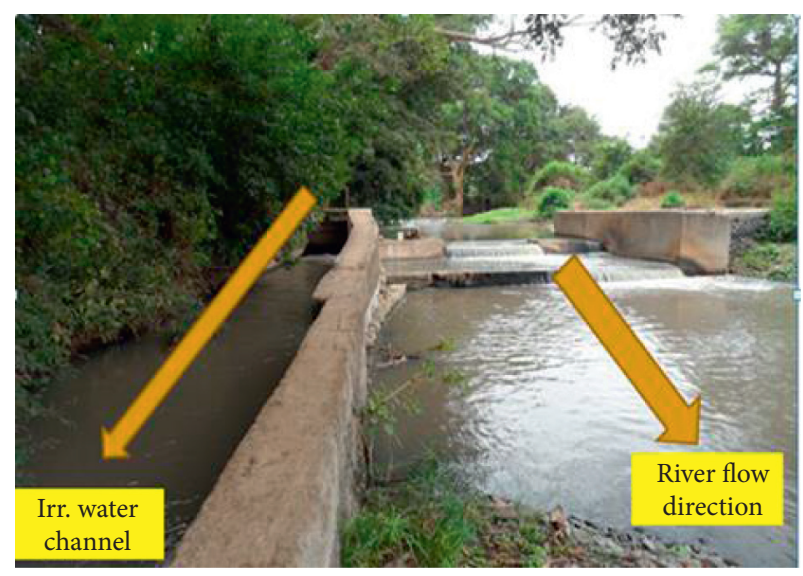

FIGURE 6: Furrow intake with no river training.

abstract water from the source locally and conveys the same using earth canal to the farm. Moreover, the distributing structure like junction, turnout boxes, and the gate valve farmer uses traditional material like stone, soils/earth, and tree logs

\subsection{Water Abstraction Compliances and Distributions.} About twenty (20) irrigation furrow intakes are owned by the farmer groups called Water User Associations (WUA). The main objectives of forming Water User Association are to manage sustainably water resource in their area, to educate and advise water uses and productivity, to resolve water conflict, for participatory management of water resource and environment, and to identify new members [9]. Each furrow intake has a management team which is called the furrow committee that is responsible for the distribution and allocation of water to its members during the dry periods. The leaders normally got problems where they were being blamed by irrigators that they do not allocate water equally and fairly. This was revealed after water flow measurement at the intakes where twelve (12) out of twenty (20) furrow intakes, which is equal to $60 \%$, abstract more water relative to the granted permits (Table 1). The data explains that reasons are due to unavailable control and regulating structures or being subject to operational management on water allocation for irrigation in a particular furrow. This is true at the catchment because Water User Association (WUA) called "UWAMAKIJU" committee meets once every week discussing issues of water allocation and distribution, resolving conflict, and coming up with a resolution as per articles of association of "UWAMAKIJU" during the dry season. In this research, an irrigation infrastructure has shown inefficiency of water supply controls at the intake, because the diverted water from the source/intake is higher than the discharged amount to the farm (Table 1).

3.4. Results of Crop Water Productivity. The catchment was divided into three agroecological zones: upstream, midstream, and downstream. In each zone, the crop and water productivity were calculated and showed variation in values. Under normal circumstances, every zone has got its 
constraints of crop production. Table 3 describes that total volumes of water of $2694.6 \mathrm{~m}^{3}, 6190.2 \mathrm{~m}^{3}$, and $8046.0 \mathrm{~m}^{3}$ for $1.045 \mathrm{ha}, 0.9996 \mathrm{ha}$, and 0.801 ha at downstream, midstream, and upstream, respectively, were used. Similarly, yields of $1102 \mathrm{~kg}, 892 \mathrm{~kg}$, and $701 \mathrm{~kg}$, equal to crop productivity of $1054.5 \mathrm{~kg} / \mathrm{ha}\left(0.41 \mathrm{~kg} / \mathrm{m}^{3}\right), \quad 892.4 \mathrm{~kg} / \mathrm{ha}\left(0.15 \mathrm{~kg} / \mathrm{m}^{3}\right)$, and $875.2 \mathrm{~kg} / \mathrm{ha}\left(0.09 \mathrm{~kg} / \mathrm{m}^{3}\right)$, were harvested per season.

\section{Discussion}

4.1. Water Conveyances, Losses, and Efficiency. The obtained results were analyzed using R-program and found that the correlation between distance and the loss of water in the canal is more significant since the $p$ value is less than 0.05 $(p>4.61 e-06)$ (Figure 7$)$. As the length of the irrigation channel increases, it escalates the water loss on channel, hence low conveyance efficiency (Figure 8). Subsequently, the relationship of the water losses and efficiency is mutual because when water is lost along the channels, this affects the efficiency of conveyance and vice versa (Figure 9). The phenomena of water losses are caused by temporal channels, earthen traditional canals, and insufficient size to hold a quantity of water, inefficient monitoring, and poor irrigation water management. In practice, farmers need water for irrigation while engineers and economists need the amount of water for irrigation to be realized in terms of technical efficiency and productivity.

4.2. Management of Traditional Irrigation Systems. The poverty alleviation is associated with development of irrigation infrastructure and agricultural water management and promotes welfare of rural community and economic growth by increasing agricultural production and productivity $[10,11]$. The farmers cultivate crops based on food and market need, but water is allocated as per schedule agreed. Administrator and policy-makers should insist on good practices and water use efficiency to enhance sustainability of water resource and irrigation agriculture. However, the government policies and international partners in irrigation emphasize water uses efficiencies, good agricultural practice (GAP), and sustainable water practices in irrigation systems by improving infrastructure and introducing new technology in line with irrigation scheduling to "gain efficiency" $[12,13]$. Substantial decrease of water from the sources creates pressure on stakeholders and hence raises awareness for irrigation water use. Conveniently, to satisfy the future water demand for irrigation agriculture, infrastructure improvement and water management from source and at the farm field are of vital importance. The fragmented management system and weak involvement of stakeholders exacerbated irrigation water management hence amplifying inefficiency of water resources utilization [14].

4.2.1. Compliances to Permitted Water Quantities. According to the field survey, irrigation agriculture withdraws 3, $500 \mathrm{~L} / \mathrm{s}$ out of a permitted amount of $2856.14 \mathrm{~L} / \mathrm{s}$ (Table 1); however, catchment consists of several rivers that collect water from the catchment covering an area of $320 \mathrm{~km}^{2}$ having rivers Tengeru, Malala, Maji ya Chai, Usa River, and Kikuletwa. The furrow intakes are distributed throughout the catchment from downstream to the upstream (Figure 1). However, the water abstraction is managed from Basin Water Offices (BWOs) through the water management act of 2009, Section 23 (a)(b), Section 31(2), and National Water Policy $2002[15,16]$. But the water allocation is a difficult activity because it involves two sides that are water users and policy-makers. However, planning and decision-making are supposed to be participatory, involving all stakeholders stated in the National Water Policy of 2002, Section 3.1 (iv). Different amount of water from the river's source is withdrawn in each furrow during the season of irrigation (Figure 10) and distributed among the members at furrow level. However, the management of water flows at the intakes was inefficient because more water is withdrawn relative to the permitted amount (Table 1). In this research, an irrigation infrastructure has shown inefficient water supply at the intake, because the diverted water from the source/intake is higher than the permitted amount for irrigation due to headworks malfunctioning (Table 1).

Further, abstracting much water from the river source reduces the share of the downstream water user and environmental flow and creates pressure on the catchment. Despite its importance to our lives and irrigation development, water is unevenly distributed in time, space, and quantity and is with great variations in quality. Some areas get more water than they need while others are suffering from water shortage. When there is water scarcity, food security is threatened and production of energy becomes difficult, affecting economic activity, posing a threat to environmental integrity, and creating water conflicts between the water users [17]. The fragmented planning between the water stakeholders aggravates the issue of water resource utilization making it more difficult. Additionally, the balance of water available in the river sources is not well known due to flow variation, recharge capacity which is subject to weather, and unavailable gauging stations. According to the analysis, the linear relationship of the discharge permitted from the water office and the discharge measured at the intake is not significant $(p>0.05)$ (Figure 11). Furthermore, the trend has also shown that as the water office grants more water permits, the enforcement in the water management and water control should be improved.

\subsubsection{Management of the Irrigation Infrastructure System.} The water supply for irrigation aims to be used for crop production which involves conveying water from the source. Water losses in conveyances reduce water diverted while echoing to increase crop productivity to meet the increasing world population remains a challenge [18]. Using more precise water delivery practices gives water managers more flexibility to deliver water where it is needed and when it is needed [19]. Simultaneously, the scattered schemes and positioning away from the irrigation scheme from the water source are one of the barriers to conveyance efficiency as illustrated in Table 2. Consequently, irrigation water demand 
TABLE 3: Irrigation schedule, hours, water quantity, farm size, and crop water productivity.

\begin{tabular}{|c|c|c|c|c|c|c|c|c|}
\hline Zones & $\begin{array}{l}\text { Irrigation } \\
\text { schedule }\end{array}$ & $\begin{array}{c}\text { Water (L/ } \\
\text { s) }\end{array}$ & $\begin{array}{l}\text { Time } \\
\text { (hrs) }\end{array}$ & $\begin{array}{c}\text { Volume } \\
\left(\mathrm{m}^{3}\right)\end{array}$ & $\begin{array}{c}\text { Size of farm } \\
\text { (ha) }\end{array}$ & $\begin{array}{c}\text { Yield } \\
(\mathrm{kg})\end{array}$ & $\begin{array}{c}\text { Water productivity } \\
\left(\mathrm{kg} / \mathrm{m}^{3}\right)\end{array}$ & $\begin{array}{c}\text { Crop productivity } \\
(\mathrm{kg} / \mathrm{ha})\end{array}$ \\
\hline \multirow{6}{*}{ Downstream } & 1 & 53 & 3 & 572.4 & 1.045 & & & \\
\hline & 2 & 52 & 3 & 561.6 & 1.045 & & & \\
\hline & 3 & 45 & 2.5 & 405 & 1.045 & & & \\
\hline & 4 & 42 & 4 & 604.8 & 1.045 & & & \\
\hline & 5 & 51 & 3 & 550.8 & 1.045 & & & \\
\hline & Average & 48.6 & 3.1 & 2694.6 & 1.045 & 1102 & 0.41 & 1054.545 \\
\hline \multirow{8}{*}{ Midstream } & 1 & 68 & 5.5 & 1346.4 & 0.9996 & & & \\
\hline & 2 & 57 & 6 & 1231.2 & 0.9996 & & & \\
\hline & 3 & 58 & 5 & 1044 & 0.9996 & & & \\
\hline & 4 & 51 & 4 & 734.4 & 0.9996 & & & \\
\hline & 5 & 53 & 3 & 572.4 & 0.9996 & & & \\
\hline & 6 & 52 & 4 & 748.8 & 0.9996 & & & \\
\hline & 7 & 57 & 2.5 & 513 & 0.9996 & & & \\
\hline & Average & 56.6 & 4.3 & 6190.2 & 0.9996 & 892 & 0.15 & 892.357 \\
\hline \multirow{9}{*}{ Upstream } & 1 & 47 & 6 & 1015.2 & 0.801 & & & \\
\hline & 2 & 50 & 5.5 & 990 & 0.801 & & & \\
\hline & 3 & 47 & 6 & 1015.2 & 0.801 & & & \\
\hline & 4 & 48 & 4.5 & 777.6 & 0.801 & & & \\
\hline & 5 & 45 & 7 & 1134 & 0.801 & & & \\
\hline & 6 & 50 & 6 & 1080 & 0.801 & & & \\
\hline & 7 & 45 & 6 & 972 & 0.801 & & & \\
\hline & 8 & 59 & 5 & 1062 & 0.801 & & & \\
\hline & Average & 48.9 & 5.8 & 8046.0 & 0.801 & 701 & 0.09 & 875.156 \\
\hline
\end{tabular}

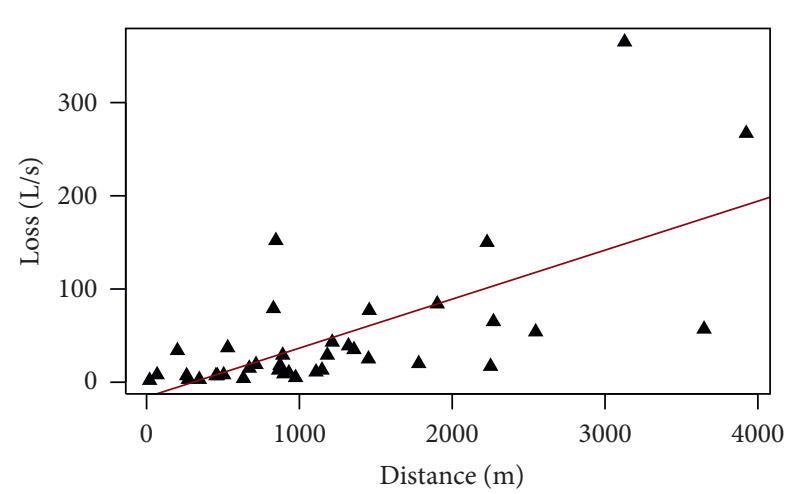

Figure 7: Loss versus distance.

is increasing globally over time with population increase, for rising income and changes in dietary preference [20]. Conveniently, to satisfy the future water demand for irrigation agriculture, infrastructure improvement and water management from source to farm field are of vital importance. Eventually, more than 850 million out of more than 1 billion are the rural poor people living on less than $1 \$$ a day depending on irrigation agriculture [11]. In the context of agroecological zones, the water competition is increasing across due to demand changes caused by population increase and climate change effect [21]. Much of the investment is needed to improve and adapt existing irrigation infrastructure systems in areas already very reliant on intensively irrigated agriculture [22] that run from upstream to the downstream across an agroecological zone of the catchment. Investing in irrigation agriculture and water management is very important because of the debate on climate change,

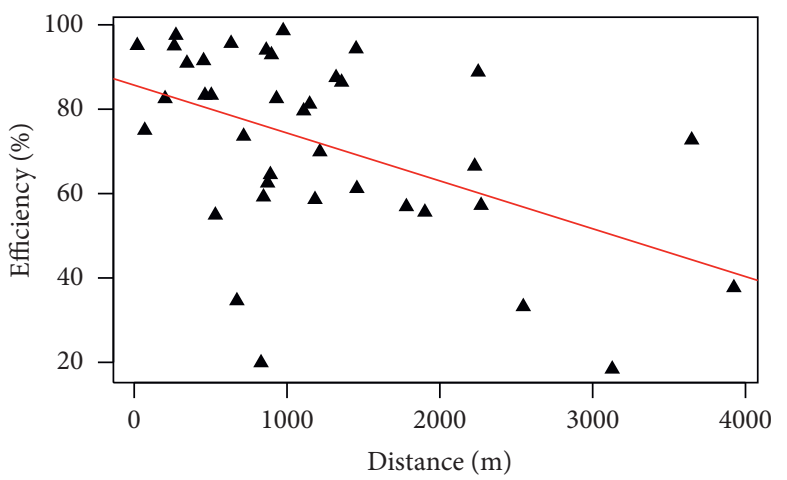

Figure 8: Efficiency versus distance.

population growth, and food security [23]. The sustainability of irrigation agriculture in terms of irrigation water supply for food production and environment uses in a catchment in question needs reliable irrigation headwork, proper and modern conveyances, application efficiency in the field, and water management enforcement. Further, access to irrigation infrastructure reduces the incidence of poverty, and upgrading watercourse saves water which results in higher cropping intensity, higher crop productivity, greater food security, and improved farm incomes [23].

4.2.3. Water Use and Crop Water Productivity. Table 3 indicates that amount of water applied for irrigation was $2694.6 \mathrm{~m}^{3}, \quad 6190.2 \mathrm{~m}^{3}$, and $8046.0 \mathrm{~m}^{3}$ with yield of $1054.5 \mathrm{~kg} / \mathrm{ha}\left(0.41 \mathrm{~kg} / \mathrm{m}^{3}\right), \quad 892.4 \mathrm{~kg} / \mathrm{ha}\left(0.15 \mathrm{~kg} / \mathrm{m}^{3}\right)$, and $875.2 \mathrm{~kg} / \mathrm{ha}\left(0.09 \mathrm{~kg} / \mathrm{m}^{3}\right)$ at downstream, midstream, and 


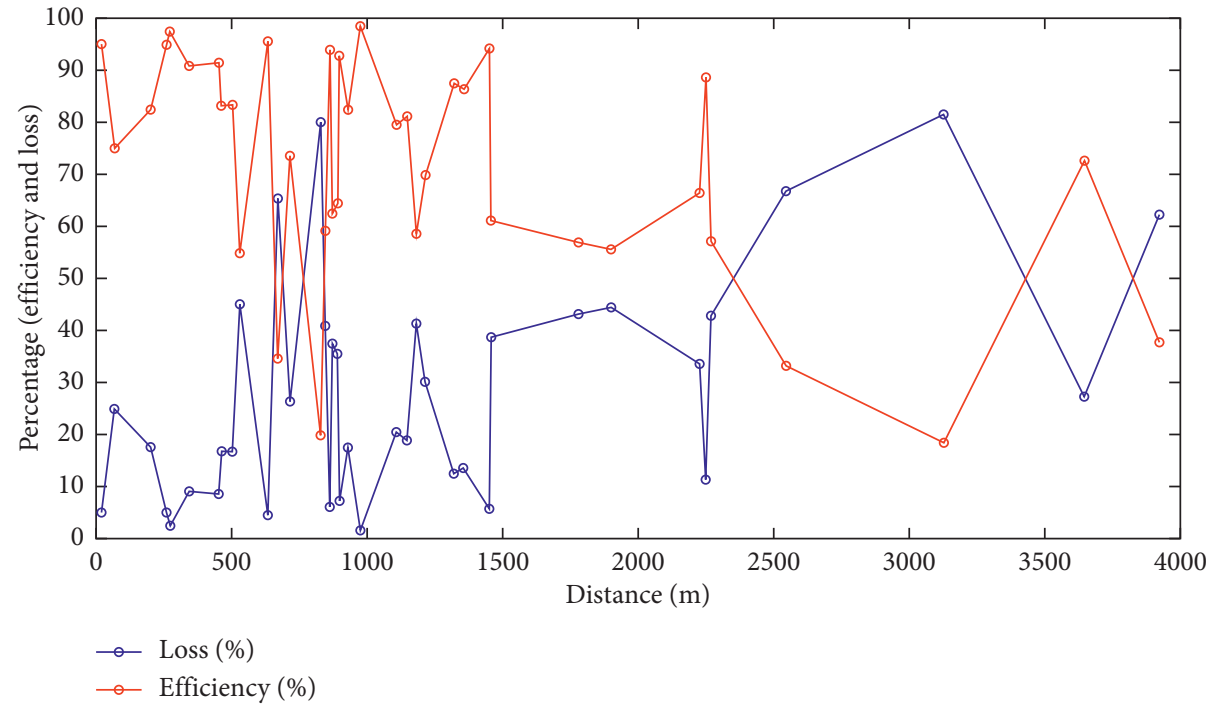

FIgURE 9: Efficiency-loss against distance.

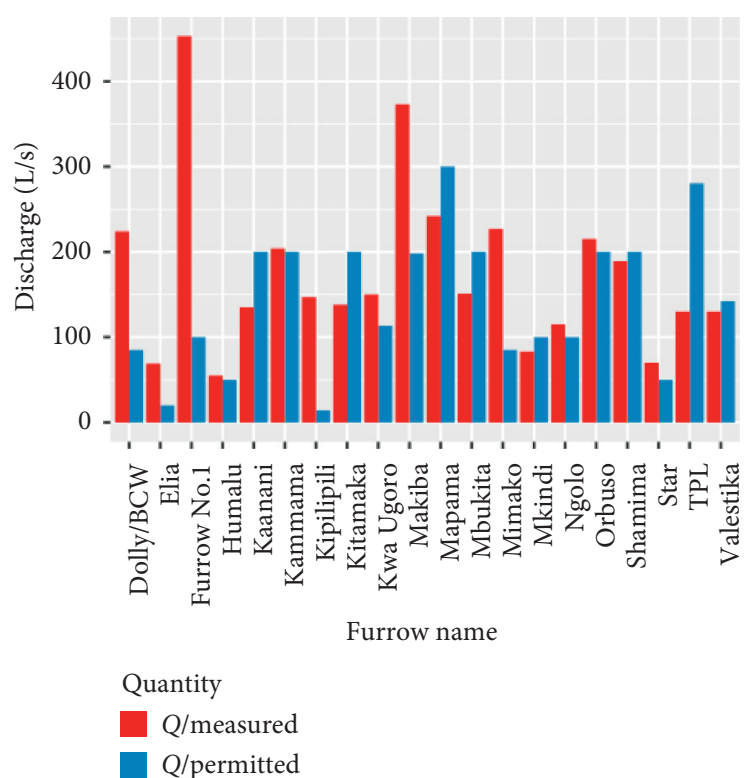

FIgURE 10: Quantity permitted and measured.

upstream, respectively, in one season; however an average conveyance efficiency is $72 \%$. At the crop level, water productivity (WP) can be defined as the ratio of biomass with economic value (for example, grain yield of cereals) over amount of water transpired (WPt) [24]. Moreover, Kijne et al. [25] defined water productivity (WP) as a measure of the ability of agricultural systems to convert water into food. Similarly, Cook et al. [26] also defined as measure of output from a given agricultural system in relation to water it consumes, which can be measured in portion or entire system. Based on the review done by Zwart and Bastiaanssen [27] and Yazar et al. [28], globally crop water productivity for maize (Zea mays L) ranges from $1.1 \mathrm{~kg} / \mathrm{m}^{3}$ to $2.7 \mathrm{~kg} / \mathrm{m}^{3}$ while in this research, it ranges from $0.09 \mathrm{~kg} / \mathrm{m}^{3}$ to $0.41 \mathrm{~kg} / \mathrm{m}^{3}$. Furthermore, in the field

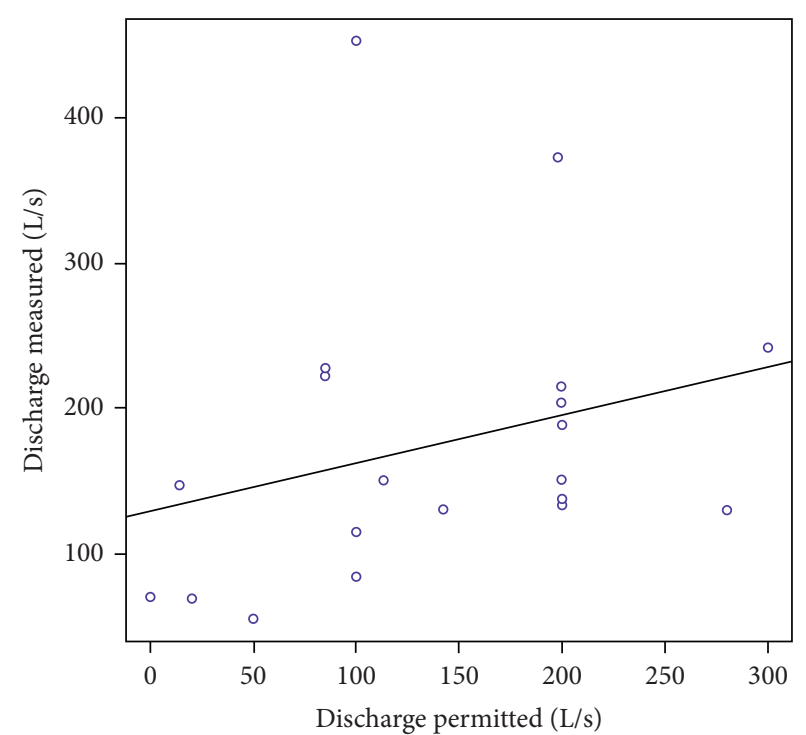

FIgURe 11: Analysis of discharge measured versus permitted.

experimental research on traditional irrigation scheme by Igbadun et al. [29], the crop water productivity of maize (Zea mays L) at Mkonji Subcatchment of Great Ruaha River Basin obtained ranges from $0.40 \mathrm{~kg} / \mathrm{m}^{3}$ to $0.55 \mathrm{~kg} / \mathrm{m}^{3}$ for the applied water. Following the results of our research and the other researchers regarding the CWP, traditional irrigation schemes have low crop water productivity, which therefore needs improvement in irrigation water management, traditional infrastructure, and water application in the field.

\section{Conclusion and Recommendations}

The traditional irrigation system in the catchment needs improvements of water utilization for easy and sustainable management of water for irrigation and enhanced agricultural crop productivity. The proper and designed 
infrastructure of the irrigation schemes contributes to reliable water allocation and efficient water supply to the destined command area. However, Usa River Catchment (URC) traditional irrigation schemes infrastructure system contains various constraints at the institutional and local level of utilization of this scarce water resource. These include water allocation, distribution, irrigation scheduling and maintenance of water channel, weak stakeholders involvement, and indifference in local and central administration. The provision of these administrative infrastructures and agronomy in the system will improve the provision of irrigation water supply services in the catchment which will be reliable and efficient. This measure will bring a positive effect to the irrigation water supply and allocation in the basins' irrigation schemes. Subsequently, water flow measurement structures are also needed to ascertain the quantity of water committed to the scheme by water office. Furthermore, land for irrigation should be monitored by keeping the farm size at a selected fertile area so that water could not be lost unnecessarily in irrigation conveyances and at farm field applications. This is important for the catchment to utilize the water resource in irrigated agriculture, water for environmental flows, and ecosystem uses by providing basin water resource management plan based on water balance, water demand, and requirement of the reserve [16]. Similarly, controlling water abstraction from the sources and illegal water abstraction as stipulated in the water policy of 2002 and the water resource management act of 2009 [16] should be enforced. Besides, the new technology of irrigation system should be introduced in the catchment for sustainability of agricultural irrigation and water resource utilization. Similarly, irrigators' involvement in water management and advising them on high value crop cultivation, water serving irrigation practices, and perpetual water flow measurement for records and decision-making on water allocation at scheme level up to the water office and decision-makers is of great importance.

\section{Data Availability}

The data can be made available upon request.

\section{Conflicts of Interest}

The authors declare that there are no conflicts of interest regarding this paper.

\section{Acknowledgments}

The authors thank the Nelson Mandela African Institution of Science and Technology and Arusha Technical College for their support.

\section{References}

[1] E. Clay, Food Security: Concepts and Measurement. Trade Reforms and Food Security: Conceptualising the Linkages, FAO, Rome, Italy, 2002.

[2] GWP. Integrated Water Resources Management. Technical Report 4, Techical Advisory Commettee, 2000.
[3] M. Adejumobi, J. Ojediran, and O. Olabiyi, "Effects of irrigation practices on some soil chemical properties on omi irrigation scheme," International Journal Engineering Research and Applications, vol. 4, no. 10, pp. 29-35, 2014.

[4] U.R.Tanzania. New Directions for Irrigation Development in Tanzania. The Context of Public Private Partnershi'p. Technical report, Ministry of Finance, Water and Irrigation and National Irrigation Commission, 2016.

[5] G. E. Van Halsema and L. Vincent, "Efficiency and productivity terms for water management: a matter of contextual relativism versus general absolutism," Agricultural Water Management, vol. 108, pp. 9-15, 2012.

[6] S. Kisnanto, R. Hadiani, and C. Ikhsan, "Infrastructure performance of irrigation canal to irrigation efficiency of irrigation area of candi limo in Mojokerto district," IOP Conference Series: Materials Science and Engineering, vol. 333, p. 12096, 2018.

[7] U. R. Tanzania, District Irrigation and Water Harvesting Support (Mainland). Support to NEPAD-CAADP Implementation TCP/URT/2908(I), Ministry of Agriculture and Irrigation, Dar es Salaam, Tanzania, 2005.

[8] U. R. Tanzania, "National water sector development 2006-2015," Technical report, Ministry of Water and Irrigation, Beijing, China, 2008.

[9] U. R. Tanzania, "National water policy," in Water Policy, pp. 1-49, International Water Stewardship Programme, Eschborn, Germany, 2002.

[10] S. T. Intizar Hussain, M. A. Hanjra and D. Wijerathna. Impact of Irrigation Infrastructure Development on Dynamics of Incomes and Poverty Econometric Evidence Using Panel Data from Sri Lanka. Technical report, International Water Management Institute (IWMI) and Japan Bank for Interantional Cooperation (JBIC) 2003.

[11] R. E. Namara, M. A. Hanjra, G. E. Castillo, H. M. Ravnborg, L. Smith, and B. Van Koppen, "Agricultural water management and poverty linkages," Agricultural Water Management, vol. 97, no. 4, pp. 520-527, 2010.

[12] F. Behnsen, "Sustainable water management in Usa river," International Water Stewardship Programme, pp. 1-2, 2017.

[13] R. Boelens and J. Vos, "The danger of naturalizing water policy concepts: water productivity and efficiency discourses from field irrigation to virtual water trade," Agricultural Water Management, vol. 108, pp. 16-26, 2012.

[14] K. Laoubi and M. Yamao, "Management of irrigation schemes in Algeria: an assessment of water policy impact and perspectives on development," WIT Transactions on Ecology and the Environment, vol. 125, pp. 503-514, 2009.

[15] U. R. Tanzania, "National water policy," Water Policy, 2000.

[16] U.R. Tanzania. Performance Audit Report on the Control of Water Abstraction from the Water Sources. Technical report, Ministry of Water and Irrigation Through Basins Water Boards, March 2017.

[17] D. R. Bennett, R. V. Riewe, T. Entz, and S. A. Woods, "Water conveyance and on-farm irrigation system efficiency gains in southern alberta irrigation districts from 1999 to 2012," Canadian Water Resources Journal/Revue canadienne des ressources hydriques, vol. 40, no. 2, pp. 173-186, 2015.

[18] A. J. Clemmens and D. J. Molden, "Water uses and productivity of irrigation systems," Irrigation Science, vol. 25, no. 3, pp. 247-261, 2007.

[19] L. Chapala, "Water use and productivity in a river basin," Water, vol. 21, no. 5, pp. 278-310, 2000. 
[20] C. De Fraiture and D. Wichelns, "Satisfying future water demands for agriculture," Agricultural Water Management, vol. 97, no. 4, pp. 502-511, 2010.

[21] E. Akkuzu, H. B. Ünal, and B. S. Karataş, "Determination of water conveyance loss in the menemen open canal irrigation network," Turkish Journal of Agriculture and Forestry, vol. 31, no. 1, pp. 11-22, 2007.

[22] H. Turral, M. Svendsen, and J. M. Faures, "Investing in irrigation: reviewing the past and looking to the future," $A g$ ricultural Water Management, vol. 97, no. 4, pp. 551-560, 2010.

[23] F. A. Ward, "Financing irrigation water management and infrastructure: a review," International Journal of Water Resources Development, vol. 26, no. 3, pp. 321-349, 2010.

[24] B. Bouman, "A conceptual framework for the improvement of crop water productivity at different spatial scales," Agricultural Systems, vol. 93, no. 1-3, pp. 43-60, 2007.

[25] J. W. Kijne, R. Barker, and D. J. Molden, Water Productivity in Agriculture: Limits and Opportunities for Improvement, Cabi, Wallingford, UK, 2003.

[26] S. Cook, F. Gichuki, and H. Turral, "Water productivity: estimation at plot, farm and basin scale," p. 144, CIAT, Cali, Colombia, 2006.

[27] S. J. Zwart and W. G. M. Bastiaanssen, "Review of measured crop water productivity values for irrigated wheat, rice, cotton and maize," Agricultural Water Management, vol. 69, no. 2, pp. 115-133, 2004.

[28] A. Yazar, F. Gökçel, and M. Sezen, "Corn yield response to partial rootzone drying and deficit irrigation strategies applied with drip system," Plant, Soil and Environment, vol. 55, no. 11, pp. 494-503, 2009.

[29] H. E. Igbadun, H. F. Mahoo, A. K. Tarimo, and B. A. Salim, "Crop water productivity of an irrigated maize crop in mkoji sub-catchment of the great ruaha river basin, Tanzania," Agricultural Water Management, vol. 85, no. 1-2, pp. 141-150, 2006. 